\title{
ANALISIS FUNGSI NARASI MODEL VLADIMIR PROPP DALAM FILM SURAT DARI PRAHA
}

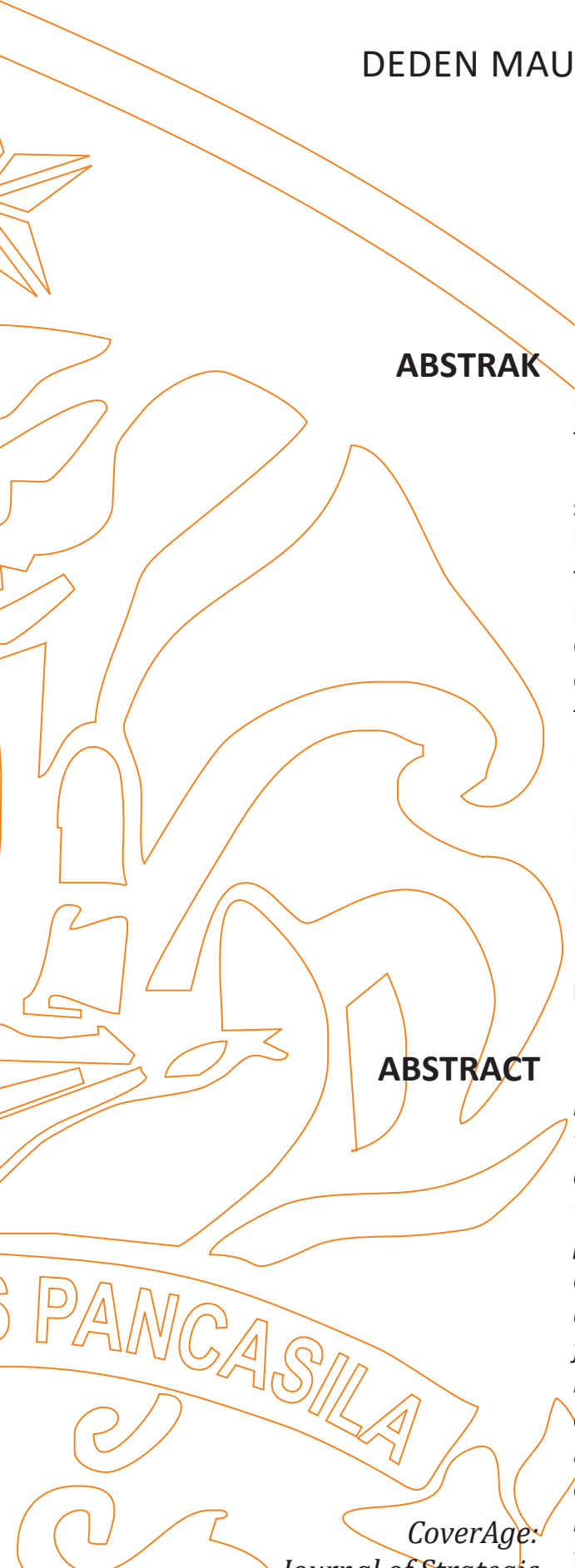

Journal of Strategic Communication

Vol. 10, No. 2, Hal. 40-58.

Maret 2020

\author{
Universitas Darussalam (UNIDA) Gontor ${ }^{1}$ \\ Email: kangdedenmd@gmail.com \\ UIN Syarif Hidayatullah Jakarta² \\ Email: badruzzaman17@gmail.com \\ DARAJAT ${ }^{1}$
}

\& MUHAMMAD BADRUZZAMAN² 


\section{PENDAHULUAN}

Film merupakan media komunikasi yang dapat menjangkau pemirsa lebih luas yang relatif masih berusia muda, sehingga film cenderung bisa memengaruhi moral masyarakat (Budiharsono: 2003). Aspek cerita dan tema sebuah film terdapat di dalam narasi. Cerita dikemas ke dalam bentuk sekenario, sehingga dapat melihat unsur-unsur seperti tokoh, masalah, konflik, lokasi, waktu serta lainnya. Seluruh unsur-unsur tersebut membentuk sebuah jalinan peristiwa terkait oleh sebuah aturan yakni hukum kasualitas (Pratista: 2008).

Film dapat dikatakan sebagai media komunikasi yang unik dibanding dengan media lainnya, karena sifatnya yang bergerak secara bebas dan tetap, penerjemahannya langsung melalui gambar-gambar visual dan suara yang nyata, juga memiliki kesanggupan untuk menangani berbagai subjek yang tidak terbatas ragamnya (Pranajaya: 2000). Sehingga bisa menjadi sarana rekreasi dan edukasi, di sisi lain dapat pula berperan sebagai penyebarluasan nilai-nilai budaya baru (Suryapati: 2010).

Film Surat dari Praha yang disutradarai Angga Dwimas Sasongko ini mewakili Indonesia dalam kategori Best Foreign Language Film di ajang Academy Awards (Oscar) 2017 (goodnewsfromindonesia.id: 2016). Sebelum maju ke piala Oscar, film ini juga mendapat penghargaan pada Usmar Ismail Awards 2016. Penghargaan tersebut antara lain untuk kategori Film Terbaik, Sutradara Terbaik yang diraih oleh Angga Dwimas Sasongko dan Pemeran Utama Pria Terbaik yang diraih oleh Tyo Pakusadewo (republika.co.id: 2016).

Film Surat dari Praha terinspirasi dari kisah pelajar Indonesia di Praha yang tidak bisa kembali ke Tanah Air karena perubahan situasi politik orde baru tahun 1966. Menyisipkan lagu "Tanah Air Beta" dalam salah satu adegannya, memunculkan ironi ketika para putera bangsa dengan rasa cinta begitu besar terhadap Indonesia, justru tak mendapat perlindungan dari tanah air mereka dan harus menyingsing masa tua di negeri orang. Hal itu sebagai dampak terjadinya gejolak politik tatkala kepemimpinan Soekarno digantikan oleh orde baru yang dipimpin oleh Soeharto. Beberapa mahasiswa yang menyatakan diri anti terhadap orde baru pun kehilangan kewarganegaraan mereka, dicap sebagai komunis serta pengkhianat bangsa. Alhasil, mereka tak bisa kembali pulang ke tanah air.
Film Surat dari Praha menceritakan kisah Larasati (Julie Estelle), seorang gadis cantik yang terpaksa memenuhi wasiat ibunya, Sulastri (Widayawati), untuk mengirimkan sebuah kotak dan surat kepada Jaya (Tyo Pakusadewo), pria paruh baya yang tinggal di Praha. Jaya adalah mantan tunangan ibunya, yang ternyata terjebak situasi ketika suhu politik Indonesia memanas pada awal era orde baru. Awalnya, Larasati hanya berniat meminta tanda tangan sebagai bukti penerimaan kotak dan surat tersebut, tapi penolakan dari Jaya serta beberapa kejadian tak terduga memaksanya tinggal lebih lama di Praha. Larasati perlahan mempelajari masa lalu antara Jaya dan Ibunya lewat lagu-lagu, juga surat hasil tulisan Jaya setelah puluhan tahun menghilang.

Cinta, perjuangan entah terhadap negeri atau kepada satu orang setia yang melingkupi kehidupan karakternya. Dua rasa cinta itu nyatanya menjadi sumber kebahagiaan sekaligus kegetiran yang coba dipendam, dilupakan sebagai masa lalu. menghadapi masa lalu yang kelam dan memaafkan segala hal termasuk kondisi dan diri sendiri menjadi fokus utama penceritaan. Cerita yang mampu membawakan tema perjuangan Larasati tanpa kehilangan kekuatan dari film Surat dari Praha itu sendiri. Di dalam film ini banyak terdapat adegan dan dialog yang mengandung makna perjuangan.

Penelitian ini menggunakan model Vladimir Propp, serta untuk memberikan aparesiasi terhadap karya seorang pekerja media yang tentunya juga memiliki ideologi tertentu dalam memandang realitas kehidupan, yang kemudian dijadikan sebagai isu untuk ditonjolkan kepada masyarakat. Penelitian ini dibatasi hanya dengan mengkaji pada pesan yang terdapat pada isi teks narasi adegan dan dialog dari film Surat dari Praha yang berkaitan dengan Perjuangan.

\section{TINJAUAN PUSTAKA}

\section{Film}

Film merupakan salah satu bagian dari audio visual yang berarti suatu cara menyampaikan dan sekaligus merangsang penglihatan dan pendengaran. Sedangkan secara etimologis, film adalah gambar hidup, cerita hidup, menurut beberapa pendapat, film adalah susunan gambar yang ada dalam selluloid, kemudian diputar dengan mempergunakan teknologi proyektor yang sebetulnya telah menawarkan nafas demokrasi, dan bisa ditafsirkan dalam berbagai makna (Prakoso: 
1997). Alex Sobur (2001) mengungkapkan bahwa, film merupakan bayangan yang diangkat dari kenyataan hidup yang dialami dalam kehidupan sehari-hari. Film atau gambar hidup merupakan gambar-gambar dalam frame, di mana frame demi frame diproyeksikan melalui lensa proyektor secara mekanis sehingga pada layar terlihat gambar itu hidup. Film bergerak dengan cepat dan bergantian sehingga memberikan daya tarik tersendiri (Arsyad: 2003).

\section{Struktur Naratif}

\section{a. Pengertian Naratif}

Naratif adalah suatu rangkaian peristiwa yang berhubungan satu sama lain dan terikat oleh logika sebab akibat yang terjadi dalam suatu ruang dan waktu. Sebuah kejadian tidak bisa terjadi begitu saja tanpa ada alasan yang jelas. Segala hal yang terjadi pasti disebabkan oleh sesuatu dan terikat satu sama lain oleh hukum sebab akibat. Dalam sebuah film cerita sebuah kejadian pasti disebabkan oleh kejadian sebelumnya.

Misalnya, pada shot A tampak seorang bocah sedang menendang bola dan shot $B$ memperlihatkan kaca jendela yang pecah. Shot $B$ terjadi karena shot $A$. penonton akan mudah memahaminya karena adanya hubungan sebab akibat. Penonton secara sadar juga mengetahui jika lokasi dua peristiwa tersebut berdekatan dan terjadi dalam waktu yang singkat. Namun jika urutannya dibalik menjadi shot $B$ lalu shot $A$. penonton akan sulit memahami karena tidak ada hubungan logika antara kaca yang pecah dengan seorang bocah yang menendang bola (Pratista: 2008).

\section{b. Pola Struktur Naratif}

Pola struktur naratif dalam film secara umum dibagi menjadi tiga tahapan yakni, permulaan, pertengahan, serta penutupan. Tahap pembukaan biasanya hanya memiliki panjang cerita seperempat durasi filmnya. Tahap pertengahan adalah yang paling lama dan biasanya panjangnya lebih dari separuh dari durasi film (Pratista: 2008).
Tabel 1.

Pola Struktur Naratif

\begin{tabular}{|c|c|c|}
\hline Permulaan & Pertengahan & Penutupan \\
\hline $\begin{array}{c}\text { Aspek ruang } \\
\text { dan }\end{array}$ & Konflik & $\begin{array}{c}\text { Konfrontasi } \\
\text { Akhir }\end{array}$ \\
\hline $\begin{array}{c}\text { Waktu para } \\
\text { pelaku }\end{array}$ & Konfrontasi & Resolusi \\
\hline Masalah & $\begin{array}{c}\text { Pengembangan } \\
\text { masalah }\end{array}$ & Tujuan \\
\hline
\end{tabular}

Sumber: Pratista, 2008

\section{c. Urutan Waktu}

Urutan waktu menunjuk pada pola berjalannya waktu cerita sebuah film. Urutan waktu cerita secara umum dibagi menjadi dua macam pola yakni, linier dan nonlinier (Pratista: 2008).

\section{Pola Linier}

Plot film sebagian besar dituturkan dengan pola linier di mana waktu berjalan sesuai urutan aksi peristiwa tanpa adanya interupsi waktu yang signifikan. Penuturan cerita secara linier memudahkan kita untuk melihat hubungan kasualitas jalinan satu peristiwa dengan peristiwa lainnya. Jika urutan waktu cerita dianggap sebagai A-B-C-D-E maka urutan waktu plotnya juga sama, yakni A-B-C-D-E. Jika misalnya cerita film berlangsung selama sehari, maka penuturan kisahnya disajikan secara urut dari pagi, siang, sore, hingga malam harinya.

\section{Pola Nonlinier}

Nonlinier adalah pola urutan waktu plot yang jarang digunakan dalam film cerita. Pola ini memanipulasi urutan waktu kejadian denagn megubah urutan plotnya sehingga membuat hubungan kausalitas menjadi tidak jelas. Pola nonlinier cenderung menyulitkan penonton untuk bisa mengikuti alur cerita filmnya. Jika urutan waktu cerita dianggap A-B-C-D-E maka urutan waktu plotnya dapat C-D-E-A-B atau D-B-C-A-E atau lainnya. Jika cerita film berlangsung selama sehari, maka penuturan kisahnya disajikan secara tidak urut, misalkan malam, pagi, sore, dan siang. Tentu saja pola seperti ini akan menyulitkan penonton untuk memahami ceritanya (Pratista: 2008).

\section{Teori Narasi}

Dari sisi etimologis, Narrative berasal dari bahasa latin "narrare", menunjukkan berbagai keterangan tentang sebuah kejadian. Ini berarti 
menyampaikan apa yang terjadi, jelas William $\mathrm{F}$. Woo dalam tulisan "Just write what happened: imposing a narrative structure doesn't always work" (Santana: 2005). Narasi adalah suatu bentuk wacana yang berusaha menggambarkan dengan sejelas-jelasnya kepada pembaca mengenai suatu peristiwa yang telah terjadi. Narasi mendefinisikan di mana, bagaimana berbagai hal bisa terjadi, kapan hal-hal tersebut terjadi, dan seberapa cepat hal-hal tersebut terjadi (Burton: 2006).

Secara umum, analisis naratif mengharuskan kita mengungkap struktur benda-benda kultural. Menaruh perhatian pada narasi mensyaratkan kita tidak "terseret" oleh kisah tersebut, tetapi tetap tidak menolak sikap untuk mempercayainya. Kita menginterupsi kisah guna menganalisis dan menyelidikinya. Sebuah kisah yang baik selalu menyembunyikan mekanismenya sehingga jangan sampai teks membuat kita lupa bahwa yang kita hadapi adalah sebuah narasi. Dalam analisis, kita perlu mengadopsi satu jarak kritis agar dapat memahami lebih baik bagaimana sebuah kisah dibangun (Stokes: 2007).

\section{Model Analisis Narasi Vladimir Propp}

Propp, lengkapnya Vladimir Jakovlevic Propp, lahir 17 April 1895 di St. Petersburg, Rusia adalah seorang peneliti sastra yang pada masa 1920-an banyak berkenalan dengan tokoh-tokoh Formalis Rusia. Propp menyadari bahwa suatu cerita pada dasarnya memiliki konstruksi. Konstruksi itu terdiri atas motif-motif yang terbagi dalam tiga unsur, yaitu pelaku, perbuatan, dan penderita. la melihat bahwa tiga unsur itu dapat dikelompokkan menjadi dua bagian, yaitu unsur yang tetap dan unsur yang berubah. Unsur yang tetap adalah perbuatan, sedangkan unsur yang berubah adalah pelaku dan penderita.Teori Propp diilhami oleh strukturalisme dalam ilmu bahasa (linguistik) sebagaimana dikembangkan oleh Saussure.

Di dalam narasi terdapat karakter, yakni orang atau tokoh yang mempunyai sifat atau prilaku tertentu. Karakter-karakter tersebut masingmasing mempunyai fungsi dalam narasi sehingga narasi menjadi koheren (menyatu). Narasi tidak hanya menggambarkan isi, tetapi juga di dalamnya terdapat karakter-karakter. Dengan adanya karakter akan memudahkan bagi pembuat cerita dalam mengungkapkan gagasannya (Erianto: 2013).

Propp tidak tertarik dengan motivasi psikologis dari masing-masing karakter. la lebih melihat karakter itu sebagai sebuah fungsi dalam narasi
(Berger: 2003). Masing-masing karakter menempati fungsi masing-masing dalam suatu narasi, sehingga narasi menjadi utuh. Fungsi di sini dipahami sebagai sebagai tindakan dari sebuah karakter, didefinisikan dari sudut pandang signifikasinya sebagai bagian dari tindakannya dalam teks. Fungsi di sini dikonseptualisasikan oleh Propp lewat dua aspek. Pertama, tindakan dari karakter tersebut dalam narasi. Tindakan atau perbuatan apa yang dilakukan oleh karakter atau aktor. Perbedaan antara tindakan dari satu karakter dengan karakter lain. Bagaimana masing-masing tindakan itu membentuk makna tertentu yang ingin disampaikan oleh pembuat cerita. Kedua, akibat dari tindakan dalam cerita (narasi). Tindakan dari aktor atau karakter akan memengaruhi karakter-karakter lain dalam cerita (Erianto: 2013).

Fungsi adalah perbuatan dari karakter atau peran cerita, yang ditetapkan dari sudut pandang keterkaitannya dengan rangkaian aksi. Propp membagi fungsi menjadi tiga puluh satu fungsi di mana satu fungsi memiliki peran mandiri (Stam et.al, 1998: 80-81). Salah satu contohnya adalah alpha $(\alpha)$ untuk situasi inisial (inisiation status) yang menjelaskan bagaimana anggota keluarga diperkenalkan atau pahlawan diperkenalkan (members of family introduced or hero introduced). Sebagai contoh yang lain adalah fungsi $\mathrm{H}$ untuk perjuangan (struggle) di mana pahlawan dan penjahat bertarung (hero and villain join in direct combat) (Berger: 2003). Fungsi H dapat kita terapkan pada pertarungan (struggle) antara Batman (hero) dengan Bane (villain) dalam film The Dark Knight Rises tahun 2012. 
Tabel 2.

Fungsi Propp

\begin{tabular}{|c|c|c|c|}
\hline \multicolumn{3}{|r|}{ Fungsi } & \multirow{2}{*}{ Deskripsi } \\
\hline No. & Simbol & Nama Fungsi & \\
\hline & $\alpha$ & Initial Situation & Anggota keluarga diperkenalkan \\
\hline 1. & $\beta$ & Absentation & Salah satu anggota keluarga tidak hadir \\
\hline 2. & $\gamma$ & Interdiction & Larangan ditujukan kepada pahlawan (bisa sebaliknya) \\
\hline 3. & $\delta$ & Violation & Larangan dilanggar \\
\hline 4. & $\varepsilon$ & Reconnaissance & Penjahat berupaya untuk mendapatkan informasi \\
\hline 5. & $\xi$ & Delivery & Penjahat mendapatkan informasi tentang korban \\
\hline 6. & $\eta$ & Trickery & Penjahat mencoba untuk menipu korban \\
\hline 7. & $\theta$ & Complicity & Korban tertipu \\
\hline \multirow{2}{*}{8.} & A & Villainy & penjahat menyebabkan kerugian bagi anggota keluarga; atau \\
\hline & a & Lack & Anggota keluarga tidak memiliki sesuatu, menginginkan sesuatu \\
\hline 9. & B & Mediation & Kesialan diketahui; pahlawan dikirim \\
\hline 10. & $\mathbf{C}$ & Counter-action & Pahlawan (pencari) setuju untuk penentangan \\
\hline 11. & $\uparrow$ & Deprature & Pahlawan meninggalkan rumah \\
\hline 12. & D & 1st donor function & Pahlawan diuji, menerima agen magis atau pembantu \\
\hline 13. & $\mathbf{E}$ & Hero's reaction & Pahlawan bereaksi terhadap agen atau donor \\
\hline 14. & $\mathbf{F}$ & $\begin{array}{l}\text { Receipt of a magical } \\
\text { agent }\end{array}$ & Pahlawan menerima fungsi agen magis \\
\hline 15. & G & Guidance & Pahlawan memimpin pada objek pencarian \\
\hline 16. & $\mathbf{H}$ & Struggle & Pahlawan dan penjahat terlibat pertarungan langsung \\
\hline 17. & 1 & Branding & Pahlawan diberi gelar \\
\hline 18. & $J$ & Victory & Penjahat dikalahkan \\
\hline 19. & K & Liquidation & kemalangan awal atau kelemahan dihancurkan \\
\hline 20. & $\downarrow$ & Return & Pahlawan kembali \\
\hline 21. & $\operatorname{Pr}$ & Pursuit, Chase & Pahlawan dikejar \\
\hline 22. & Rs & Rescue & Pahlawan selamat dari kejaran \\
\hline 23. & $\mathbf{0}$ & Unrecognized arrival & $\begin{array}{l}\text { Pahlawan, tanpa diketahui/diakui, pulang ke rumah, atau tempat } \\
\text { lain. }\end{array}$ \\
\hline 24. & $\mathbf{L}$ & Unfounded claims & False hero menyajikan klaim tanpa dasar \\
\hline 25. & M & Difficult task & Tugas sulit dibebankan pada pahlawan \\
\hline 26. & $\mathbf{N}$ & Solution & Tugas diselesaikan \\
\hline 27. & $\mathbf{R}$ & Recognition & Pahlawan diakui/dihormati \\
\hline 28. & Ex & Exposure & False hero atau penjahat terekspos \\
\hline 29. & $\mathbf{T}$ & Transfiguration & Pahlawan diberikan penampilan baru \\
\hline 30. & $\mathbf{U}$ & Punishment & Penjahat dihukum \\
\hline 31. & W & Wedding & Pahlawan menikah, naik takhta. \\
\hline
\end{tabular}


Peran cerita dalam sebuah narasi dirumuskan Propp dalam tujuh dramatis personae yaitu sebagai pemeran cerita dalam naratif. Ketujuh peran ini adalah:

1. Villain (bertarung dengan hero)

2. Hero (mencari sesuatu dan bertarung dengan villain)

3. Donor (mendukung hero dengan agen atau kekuatan magis)

4. Penolong (membantu hero menyelesaikan tugas yang sulit)

5. Putri (tokoh yang dicari), Bapak dari putri (memberikan tugas yang sulit)

6. Dispatcher (mengirim hero pada misinya)

7. False hero (mengklaim sebagai hero tapi akhirnya terungkap kepalsuanya)

\section{METODE}

Penelitian ini menggunakan metode kualitatif dan analisis narasi (narative analysis) yaitu studi tentang struktur pesan atau telaah mengenai aneka fungsi bahasa (pragmatic) (Sobur: 2001). Dalam pendekatan ini, penulis menggunakan metode yang langsung menarasikan dalam bentuk penjelasan kualitatif tentang fenomena yang dibahas. Pendekatan ini bertujuan untuk memahami makna sehingga dapat menggambarkan makna perjuangan dari film Surat dari Praha. Dengan metode ini, tidak hanya diketahui pesan apa saja yang terkandung dalam Film Surat dari Praha, tetapi bagaimana pesan itu dikemas dan diatur sedemikian rupa dalam bentuk cerita. Melalui analisis narasi tidak hanya mengetahui isi teks. Tetapi bagaimana juga pesan itu disampaikan lewat cerita. Macam apa yang disampaikan. Analisis narasi lebih melihat bagaimana isi pesan yang akan diteliti.

\section{HASIL DAN PEMBAHASAN}

Dalam bab ini penulis akan memaparkan temuan data dan hasil analisis penelitian yang terdapat dalam film Surat dari Praha, sesuai dengan teori yang penulis gunakan yaitu analisis model Vladimir Propp untuk menganalisis karakterisasi tokoh yang terdapat dalam film Surat dari Praha. Berikut adalah hasil temuan yang berkaitan dengan teori di atas :

\section{Analisis Fungsi Narasi Propp Makna Perjuangan Larasati}

Dalam fungsi pelaku terdapat ringkasan cerita, fungsi, definisi, dan lambang. Fungsi pelaku menggambarkan fungsi di mana seorang tokoh atau pelaku bertidak sesuatu. Dari fungsi tertentu kemudian didefinisikan ke dalam suatu peristiwa. Definisi yang menunjukan suatu peristiwa akan diberi lambang dengan kode-kode tertentu, misalnya suatu ringkasan scene menempati seorang pahlawan meninggalkan rumah didefinisikan suatu pemergian dan dilambangkan dalam rangkaian fungsi pelaku sebutan tokoh di bagian fungsi, tidak dijelaskan dengan nama tokoh tersebut namun menggunakan istilah pahlawan, penjarah, donor atau pembekal. Pahlawan merupakan tokoh sentral yang selalu hadir hampir dalam setiap peristiwa. Penjarah adalah penjahat atau penghambat kemudian donor atau pembekal adalah orang atau alat yang membantu pahlawan saat mengalami kesulitan. Makna perjuangan fungsi pelaku dalam film Surat dari Praha akan diuraikan lebih jelas di bawah ini.

1. Adegan awal dari Film Surat dari Praha mengenalkan sosok Laras sebagai tokoh utama yang berusaha menyelesaikan masalah pribadinya dengan cara yang mudah dengan meminjam sertifikat rumah ibunya.

\section{Gambar 1.}

Adegan 1 Film Surat dari Praha mengenalkan sosok Laras

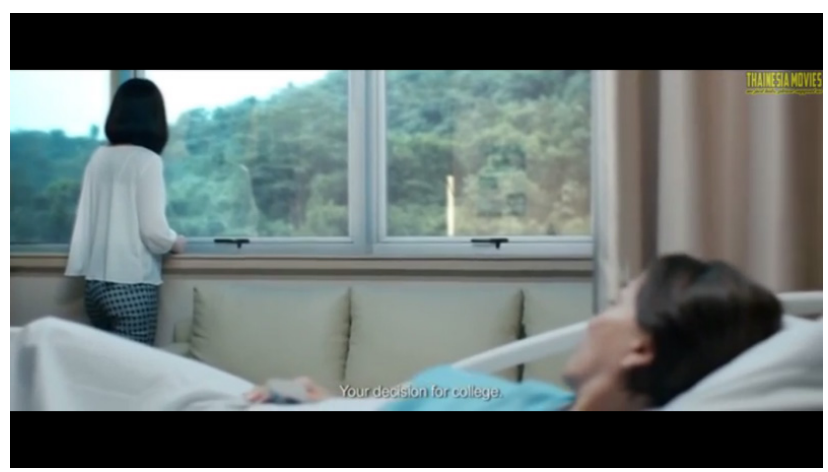

$00.01 .40-00.04 .50$

Sumber: Cuplikan Film Surat dari Praha 
Tabel 3.

Situasi Awal

\begin{tabular}{|c|c|l|}
\hline Simbol & Fungsi & \multicolumn{1}{c|}{ Deskripsi Fungsi } \\
\hline$\alpha$ & Situasi Awal & $\begin{array}{l}\text { Bagian ini dibuka dengan adegan Laras (Julie Estelle) menemui Ibunya Sulastri } \\
\text { (Widyawati) yang terbaring di rumah sakit. la berusaha meyakinkan ibunya untuk } \\
\text { meminjamkan sertifikat rumah untuk digadai. Hasilnya dipakai untuk proses } \\
\text { perceraian dengan suaminya. Sang ibu berharap Laras memikirkan kembali niat } \\
\text { untuk menceraikan suaminya. Namun Laras tetap pada keyakinannya untuk } \\
\text { meminjam sertifikat rumah dan menyelesaikan persoalan perceraiannya. }\end{array}$ \\
\hline
\end{tabular}

Sumber: Olahan Penulis

Sulastri :"Setahun lebih ibu tidak melihat kamu ... tiba-tiba sekarang muncul lalu kamu mau meminjam sertifikat tanah ... soal perceraian kamu saja ibu taunya dari tante Widia"

Laras : "yang penting sekarang ibu sudah tahu kan ..."

Sulastri : "Kamu pikir cerai sesederhana itu ..."

Laras : "Bu ... Laras udah buat keputusan, gak sulit kan, kali ini aja ibu hargai keputusan Laras"

Sulastri : "Ibu Bercerai ... Laras .." kalau kamu perlu sertifikat .. setidaknya kamu harus mendengarkan omongan ibu sampai selesai"

Laras : "Sekarang Laras tanya sama ibu .. apa yang diharepin dari laki-laki yang tidur dengan perempuan lain sementara istrinya lagi hamil dua bulan .. sampai harus keguguran .. bu laras gak pernah minta bantuan apa-apa dari ibu .. sekarang Laras minta bantuan ... tolong ibu pikirkan."

Peristiwa ini merupakan situasi awal yang berperan penting dalam urutan cerita film Surat dari Praha. Situasi awal ini tidak termasuk dalam fungsi namun mempunyai lambang seperti fungsi pelaku yaitu $\alpha$ (Erianto: 2013). Adegan awal menampilkan kondisi pertama pahlawan mendapatkan masalah sehingga harus mencari jalan keluar agar dapat diselesaikan. Situasi awal menceritakan asal-usul pahlawan dalam cerita yang perankan oleh Laras. Pahlawan ini merupakan tokoh sentral dan utama yang banyak terlibat dalam peristiwa. Setelah situasi awal kemudian dilanjutkan dengan fungsi pelaku.

2. Mendapatkan tugas yang diberikan notaris (Jajang C. Noer) sebagai syarat untuk mendapatkan warisan ibunya.

Gambar 2.

Adegan 2 Film Surat dari Praha

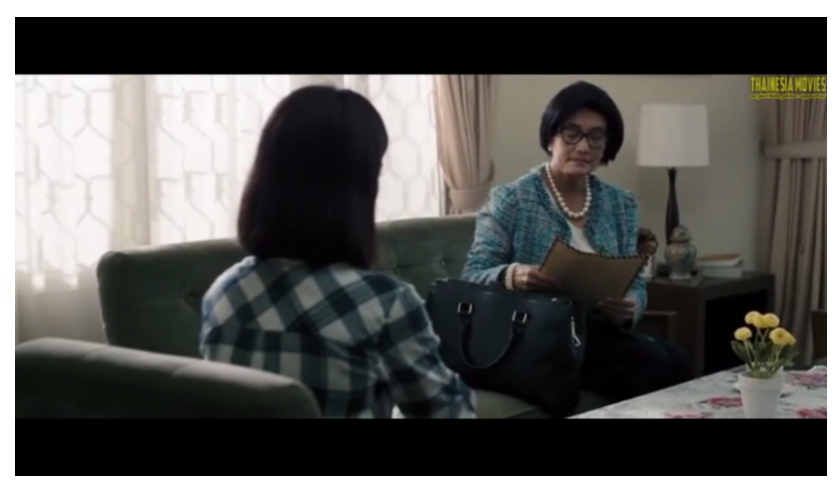

$00.10 .45-00.12 .30$

Sumber: Cuplikan Film Surat dari Praha

Tabel 4.

Tugas Berat

\begin{tabular}{|c|l|l|}
\hline Simbol & \multicolumn{1}{|c|}{ Fungsi } & \multicolumn{1}{c|}{ Deskripsi Fungsi } \\
\hline $\mathrm{M}$ & $\begin{array}{l}\text { Tugas Berat } \\
\text { (F.XXV) }\end{array}$ & $\begin{array}{l}\text { Setelah meninggalnya sang ibu (Sulastri), tidak butuh waktu lama bagi Laras } \\
\text { untuk segera mendapatkan warisan. Laras langsung menemui notaris keluarga, } \\
\text { jarak satu hari setelah kepergian sang ibu. Namun untuk mendapatkan warisan, } \\
\text { laras harus menjalankan surat wasiat yang ditulis oleh sang ibu. la diberi tugas } \\
\text { oleh notaris untuk bertemu dengan seseorang yang berada di kota Praha, Re- } \\
\text { publik Ceko, menyerahkan sebuah kotak surat dan mendapatkan tanda tangan } \\
\text { sebagai syarat mendapatkan warisan. }\end{array}$ \\
\hline
\end{tabular}

Sumber: Olahan Penulis 
Notaris :"Saya yang bertanda tangan di bawah ini .. Sulastri Kusumaningrum.. tempat tanggal lahir Jakarta 20 Juni 1946.. sebagai ibu kandung dengan sadar dan tanpa paksaan membuat pernyataan surat wasiat waris .. agar apabila saya sudah tiada, maka rumah yang saya tempati sekarang berikut seluruh isinya .. diserahkan kepada satusatunya anak saya Kemala Dahayu Larasati .. dengan syarat mutlak dilakukan setelah dirinya mengantar sebuah kotak beserta surat yang tersimpan di dalamnya, ke alamat tertera yang dibuktikan dengan selembar surat tanda terima .."

Laras : "Jadi saya harus dapat tanda tangan orang itu dulu baru bisa dapat rumah ini?"

Notaris : "Begitulah .."

Laras : "Gak ada cara lain?"

Notaris : "Tante hanya notaris .. tante hanya membacakan apa yang sudah tertera di surat wasiat .. lagipula kekuatan hukumnya sudah jelas .. tidak bisa dihindari".

Melihat dialog tersebut, terlihat bahwa perjuangan laras untuk mendapatkan warisan harus menemui jalan yang berat. Karena harus menyelesaikan wasiat dari sang ibu, barulah kemudian Laras bisa menguasai penuh harta warisannya. Pada adegan sebelumnya Laras ingin segera menyelesaikan proses perceraiannya dengan suaminya, dengan berusaha mendapatkan sertifikat rumah. Namun situasi berubah ketika sang ibu meninggal dengan harapan segera mendapatkan warisan peninggalannya harus menyelesaikan perintah wasiat yang diberikan oleh notaris untuk menyerahkan kotak surat dan mendapatkan tanda tangan Jaya sebagai syarat mendapatkan warisan. Peristiwa ini terdapat dalam fungsi narasi Propp ke25 dengan lambang M. Pahlawan diberikan tugas berat, diberikan ujian untuk membuktikan dirinya (Erianto: 2013).

3. Laras menuju kota Praha, Republik Ceko

Gambar 3.

Adegan 3 Film Surat dari Praha

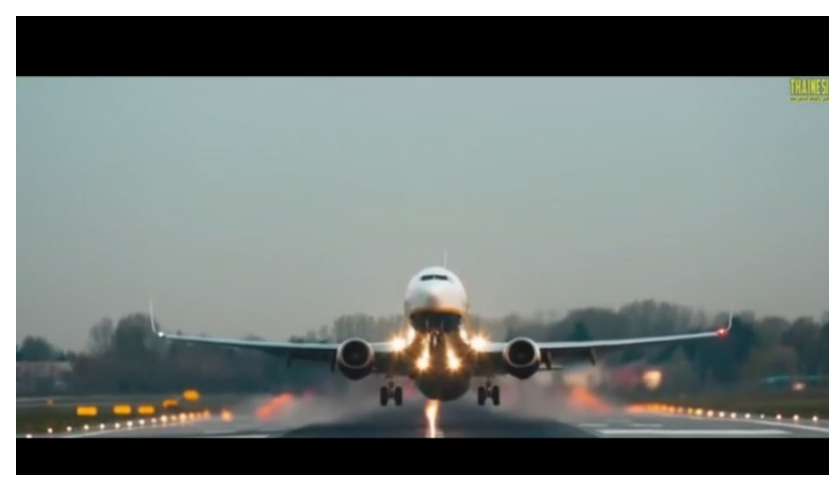

$00.12 .40-00.12 .51$

Sumber: Cuplikan Film Surat dari Praha

Tabel 5.

Keberangkatan

\begin{tabular}{|c|l|l|}
\hline Simbol & \multicolumn{1}{|c|}{ Fungsi } & \multicolumn{1}{c|}{ Deskripsi Fungsi } \\
\hline$\uparrow$ & $\begin{array}{l}\text { Keberangkatan } \\
\text { (F.XI) }\end{array}$ & $\begin{array}{l}\text { Laras menuju kota Praha, Ceko untuk menjalankan misinya menyerahkan } \\
\text { kotak surat kepada seseorang dan mendapatkan tanda tangannya. }\end{array}$ \\
\hline
\end{tabular}

Sumber: Olahan Penulis

Pada fungsi ini pahlawan meninggalkan rumah, memutuskan untuk mengejar dan menyelesaikan tugas. Dalam cerita ini menggambarkan peristiwa keberangkatan Laras menuju kota Praha yang mendapatkan tugas setelah menerima surat wasiat dari almarhum ibunya (Sulastri) yang diserahkan melalui notaris pada adegan sebelumnya. Hal inilah yang menyebabkan Laras pergi maka dapat didefinisikan keberangkatan dalam narasi Propp.

4. Laras bertemu dengan Jaya dan melakukan perbincangan terkait tugas yang diberikan oleh almarhum ibunya (Sulastri).

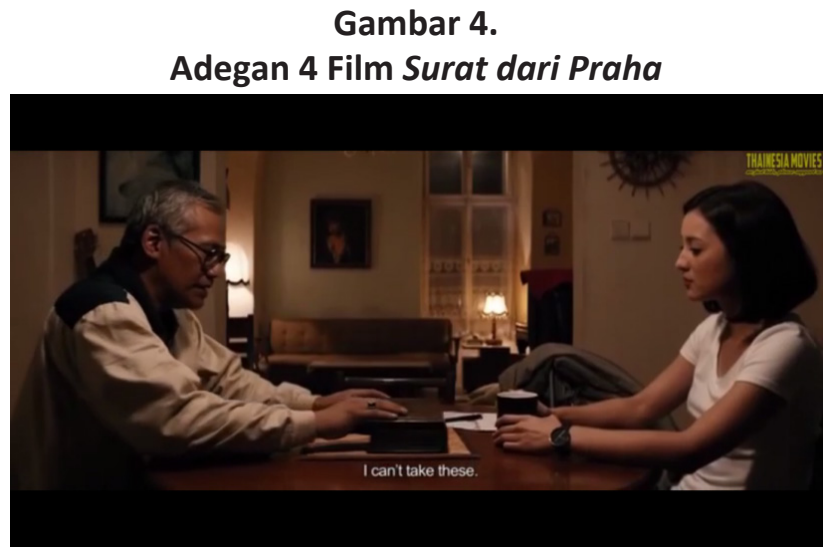

$00.17 .20-00.18 .50$

Sumber: Cuplikan Film Surat dari Praha 
Tabel 6.

Mediasi

\begin{tabular}{|c|c|l|}
\hline Simbol & Fungsi & \multicolumn{1}{c|}{ Deskripsi Fungsi } \\
\hline B & Mediasi & Laras menjelaskan prihal kedatangannya kepada Jaya di kediamannya di Praha. \\
(F.IX) & $\begin{array}{l}\text { Untuk menyerahkan sebuah kotak surat yang diberikan oleh alm ibunya (Su- } \\
\text { lastri) serta mendapatkan tanda tangannya agar tugasnya selesai. Namun Jaya } \\
\text { menolaknya sehingga terjadi perdebatan antara Laras dengan Jaya. }\end{array}$ \\
\hline
\end{tabular}

Sumber: Olahan Penulis

Laras : "Saya tidak kenal dengan anda... dan saya gak ngerti kenapa ibu saya menjadikan ini sebagai syarat atas warisannya, yang jelas saya hanya butuh anda menandatangani surat ini!!"

Jaya : "yang jelas saya tidak bisa menerima barang-barang ini .."

Laras : "Ya tapi alasannya apa?"

Jaya : :Itu urusan anda ..."

Laras : "Kok jadi urusan saya sih ... saya jauh-jauh kesini untuk dapat tanda tangan anda.. dan anda bilang ini hanya urusan saya!"

Jaya : : "Palsukan saja tanda tangan saya .. saya akan telepon taksi .. dan anda bawa barang ini semua .. anda boleh pergi dari sini .. Jelas?"

Laras : "Gak perlu .. saya bisa cari sendiri .." "Saya akan kembali besok pagi ... dan berharap anda berubah pikiran .."

Setelah sampai di kota Praha, kemudian Laras menuju rumah Jaya untuk melakukan perbincangan terkait perintah yang dikirim oleh almarhum ibunya (Sulastri). Dari dialog di atas dijelaskan bahwa perjuangan Laras untuk mendapatkan tanda tangan serta menyerahkan kotak surat mendapatkan penolakan dari Jaya. Namun Laras bersikukuh untuk mendapatkan tanda tangannya dan menyelesaikan tugasnya. Pada fungsi pelaku ini B (Mediasi), pahlawan dikirim untuk mengejar dan menjalankan misi yang telah ditugaskan kepadanya. Laras memutuskan untuk menjalankan tugasnya agar kotak surat ini diterima oleh Jaya. Dalam narasi diceritakan Laras menjelaskan kedatangannya dan berusaha membujuk Jaya untuk menerima kotak surat tersebut dan mendapatkan tanda tangannya.

5. Terjadi perampokan kepada Laras saat hendak menuju hotel.

Gambar 5.

Adegan 5 Film Surat dari Praha

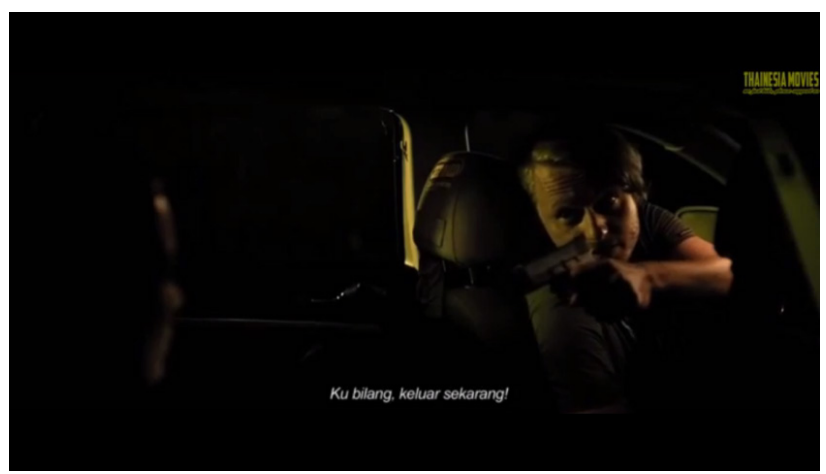

$00.20 .58-00.21 .32$

Sumber: Cuplikan Film Surat dari Praha

Tabel 7.

Kejahatan (Terjadi Perampokan)

\begin{tabular}{|c|l|l|}
\hline Simbol & \multicolumn{1}{|c|}{ Fungsi } & \multicolumn{1}{c|}{ Deskripsi Fungsi } \\
\hline A & $\begin{array}{l}\text { Kejahatan } \\
\text { (Terjadi } \\
\text { Perampokan) } \\
\text { (F.VIII) }\end{array}$ & $\begin{array}{l}\text { Laras mengalami nasib naas saat menuju hotel. la mengalami perampokan di } \\
\text { jalan oleh supir taksinya sendiri. Sehingga harus kehilangan harta bendanya dan } \\
\text { hanya menyisakan kotak surat. }\end{array}$ \\
\hline
\end{tabular}

Sumber: Olahan Penulis 
Laras : "Where are we? "Why you're stopping here?

Supir : "I think you should get out now!"

taksi "Leave your bag and get out!!"

Di tengah perjalanan menuju hotel Laras mengalami kejadian yang tak terduga. la dirampok oleh supir taksi yang ia tumpangi, di bawah terowongan yang gelap Laras ditodong dengan pistol, serta diminta untuk turun dan meninggalkan barang-barangnya. Hanya menyisakan kotak surat dan surat wasiat. Dalam narasi Propp kejahatan dalam sebuah cerita yaitu penjahat melukai pahlawan, tindakan penjahat menyebabkan kerugian atau hilangnya seseorang baik anggota keluarga maupun pahlawan (Erianto: 2013). Peristiwa ini sesuai dengan fungsi yang ke-8 dalam narasi Propp dengan lambang (A).
6. Laras meminta bantuan kepada polisi disekitar KBRI kota Praha untuk diantarkan ke rumah Jaya.

\section{Gambar 6.}

Adegan 6 Film Surat dari Praha

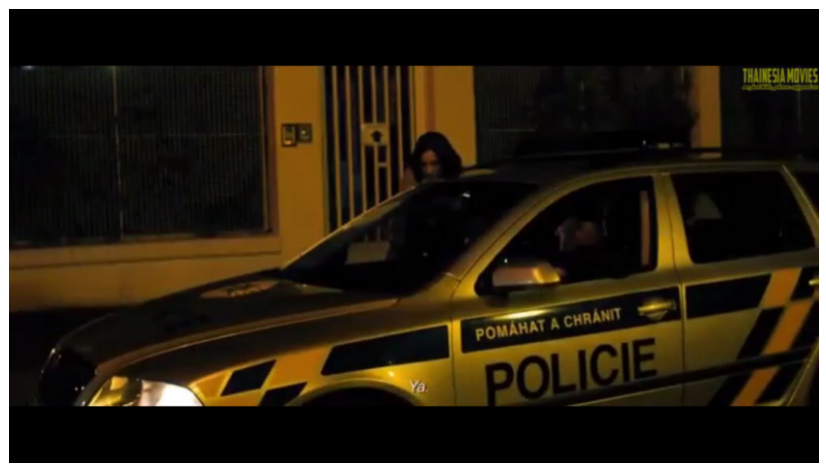

$00.25 .42-00.25 .57$

Sumber: Cuplikan Film Surat dari Praha

Tabel 8

Seorang Penolong

\begin{tabular}{|c|l|l|}
\hline Simbol & \multicolumn{1}{|c|}{ Fungsi } & \multicolumn{1}{c|}{ Deskripsi Fungsi } \\
\hline D & $\begin{array}{l}\text { Seorang } \\
\text { penolong } \\
\text { (F.XII) }\end{array}$ & $\begin{array}{l}\text { Laras mendapatkan bantuan dari polisi di sekitar Kedutaan Besar Republik } \\
\text { Indonesia (KBRI) di kota Praha. Untuk diantarkan menuju alamat yang tertera } \\
\text { pada surat. }\end{array}$ \\
\hline
\end{tabular}

Sumber: Olahan Penulis

Laras : "Can you please take me to this address?"

Polisi : "Yes..."

Setelah mengalami perampokan, Laras menuju KBRI kota Praha untuk meminta bantuan. Karena tidak mendapatkan respons dari KBRI. Laras meminta bantuan kepada Polisi, untuk diantarkan ke sebuah alamat yang tertera dalam surat. Kemudian polisi itu pun bersedia untuk mengantarkannya. Pada fungsi ini tampak jelas Laras mendapatkan pertolongan dari polisi usai mengalami perampokan. Peristiwa ini tampak pada untit naratif ke-12 dengan lambang (D) dalam narasi Propp.

7. Jaya memberikan larangan kepada laras selama tinggal dirumahnya.
Gambar 7.

Adegan 7 Film Surat dari Praha

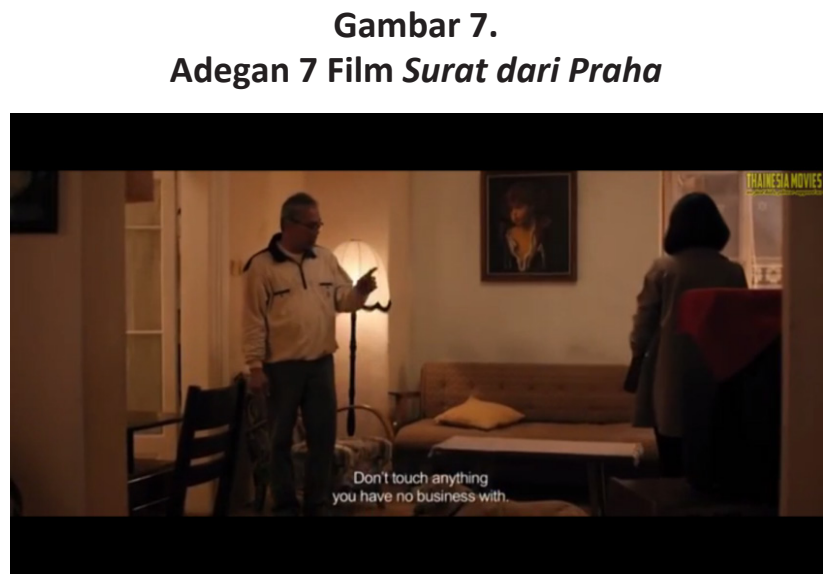

$00.26 .35-00.26 .55$

Sumber: Cuplikan Film Surat dari Praha

Tabel 9.

Pelarangan

\begin{tabular}{|c|l|l|}
\hline Simbol & \multicolumn{1}{|c|}{ Fungsi } & \multicolumn{1}{c|}{ Deskripsi Fungsi } \\
\hline $\mathrm{Y}$ & $\begin{array}{l}\text { Pelarangan } \\
\text { (F.II) }\end{array}$ & $\begin{array}{l}\text { Setelah mengalami perampokan dan kembali lagi ke rumah Jaya. Laras } \\
\text { diberikan larangan untuk tidak menyentuh hal-hal yang tidak ada hubungannya } \\
\text { dengan dia selama tinggal di rumahnya. }\end{array}$ \\
\hline
\end{tabular}

Sumber: Olahan Penulis 
Jaya : "Kamu bisa tidur disini... jangan sentuh apapun yang tidak ada hubungannya dengan kamu .."

Peristiwa perampokan yang terjadi pada Laras, membuat ia kehilangan harta benda termasuk uang. Ia pun kembali kerumah Jaya untuk tinggal sementara. Selama tinggal di rumah Jaya, Laras tidak boleh menyentuh hal-hal yang tidak ada hubungannya dengan dia. Peristiwa ini tampak pada unit naratif Propp sesuai dengan fungsi yang ke dua yaitu pelarangan dengan lambang $\gamma$.

8. Terjadi perdebatan kembali antara Laras dengan Jaya di depan KBRI kota Praha.
Gambar 8. Adegan 8 Film Surat dari Praha

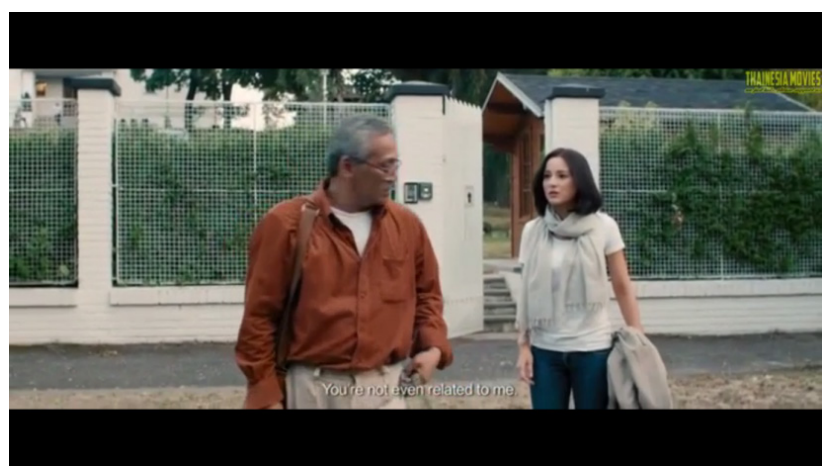

$00.28 .56-00.29 .45$

Sumber: Cuplikan Film Surat dari Praha

Tabel 10.

Mediasi

\begin{tabular}{|c|l|l|}
\hline Simbol & \multicolumn{1}{|c|}{ Fungsi } & \multicolumn{1}{c|}{ Deskripsi Fungsi } \\
\hline B & $\begin{array}{l}\text { Mediasi } \\
\text { (F.IX) }\end{array}$ & $\begin{array}{l}\text { Laras meminta untuk tetap tinggal sementara di rumah Jaya. Sampai } \\
\text { administrasi di KBRI kota Praha kembali seperti semula. Serta meminjam } \\
\text { rekening Jaya untuk mentransfer uang dari temannya di Indonesia. }\end{array}$ \\
\hline
\end{tabular}

Sumber: Olahan Penulis

Laras : "Ada pergantian duta besar .. jadi semua aktivitas diliburin ... saya diminta balik lagi hari senin"

Jaya : "Kamu bisa minta kamar satu di dalam ... bilang aja pasti dikasih .."

Laras : "Saya diminta untuk tinggal di tempat anda"

Jaya : "Situ kan bukan siapa-siapa saya"

Laras : "Ya .. kalau begitu anda masuk aja dan ngomong sendiri dengan mereka.." "Saya butuh nomer rekening Bank anda!"

Jaya : "Nanti saya pinjamkan"

Laras : "Semua uang yang saya pakai nanti saya kembalikan!"

Jaya : "sebaiknya begitu"

\section{Laras : "Anda ini siapa ibu saya sih??"}

Setelah mengetahui adanya pergantian duta besar di KBRI kota Praha, dan semua aktifitas diliburkan. Laras memutuskan untuk dapat tinggal sementara di kediaman Jaya, namun Jaya menolaknya dan bersikeras kepada Laras untuk meminta kamar dan tinggal sementara di KBRI.
Namun Laras bersikukuh untuk tetap tinggal sementara di rumah Jaya sampai KBRI kembali berjalan normal. Tidak hanya meminta untuk tinggal sementara Laras juga ingin meminjam rekening Jaya agar bisa ditransfer uang oleh temannya di Indonesia. Serta mengganti semua biaya yang dikeluarkan oleh Jaya selama membantu Laras. Namun karena sikap Jaya terkesan acuh membuat Laras berjuang untuk meyakinkannya. Peristiwa ini sesuai dengan fungsi yang ke 9 dengan lambang B.

9. Mendapatkan pertolongan dari seorang perempuan Ceko.

Gambar 9.

Adegan 9 Film Surat dari Praha

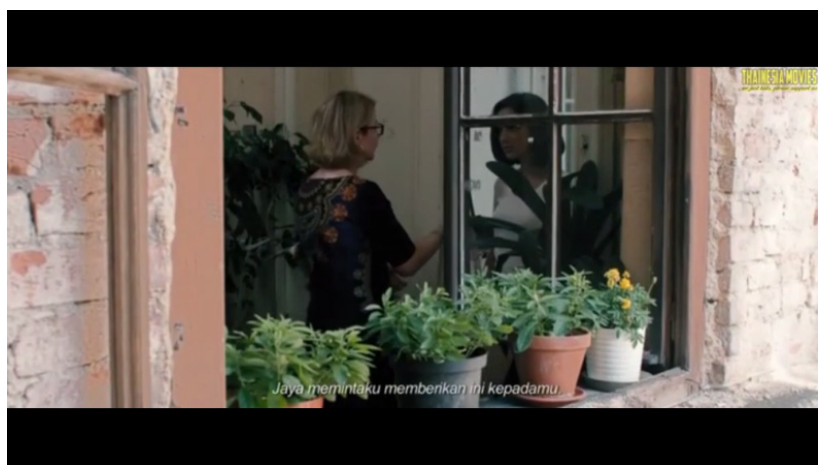

$00.33 .27-00.33 .56$

Sumber: Cuplikan Film Surat dari Praha 
Tabel 11.

Pertolongan

\begin{tabular}{|c|l|l|}
\hline Simbol & \multicolumn{1}{|c|}{ Fungsi } & \multicolumn{1}{c|}{ Deskripsi Fungsi } \\
\hline Rs & $\begin{array}{l}\text { Pertolongan } \\
\text { (F.XXII) }\end{array}$ & $\begin{array}{l}\text { Laras mendapat sebuah kiriman barang dari seorang wanita yang diutus oleh } \\
\text { Jaya yang berisi beberapa pakaian, handphone dan secarik kertas berisi nomer } \\
\text { rekening untuk menghubungi temannya di Indonesia. }\end{array}$ \\
\hline
\end{tabular}

Sumber: Olahan Penulis

$\begin{array}{ll}\text { Teman Jaya } & : \text { "Larasati?" } \\ \text { Laras } & : \text { "Ya .." } \\ \text { Teman Jaya } & : \text { "Jaya ask me to give this for } \\ & \text { you!" } \\ \text { Laras } & : \text { "Thank you" } \\ \text { Teman Jaya } & : \text { "Have a nice day" } \\ \text { Laras } & \text { : "You too" }\end{array}$

Dalam cerita tradisional (dongeng) bagian ini biasanya berupa pemberian seorang tetua atau orang sakti kepada pahlawan, berupa alat atau mantra yang bias melindungi pahlawan dalam tugasnya. Dalam film Surat dari Praha Laras mendapatkan sebuah kiriman barang dari seorang perempuan yang diketahui adalah teman Jaya di Praha. Berupa pakaian, nomor rekening dan handphone untuk keperluannya selama di Praha, karena sebelumnya laras mengalami perampokan saat menuju hotelnya dan harus kehilangan seluruh harta bendanya. Peristiwa ini sesuai dengan fungsi yang ke-12 fungsi pertama seorang penolong dengan lambang $\mathrm{D}$.
10. Laras mengambil sebuah buku dan menyanyikan sebuah lagu yang ada di buku tersebut dengan piano Jaya.

Gambar 10.

\section{Adegan 10 Film Surat dari Praha}

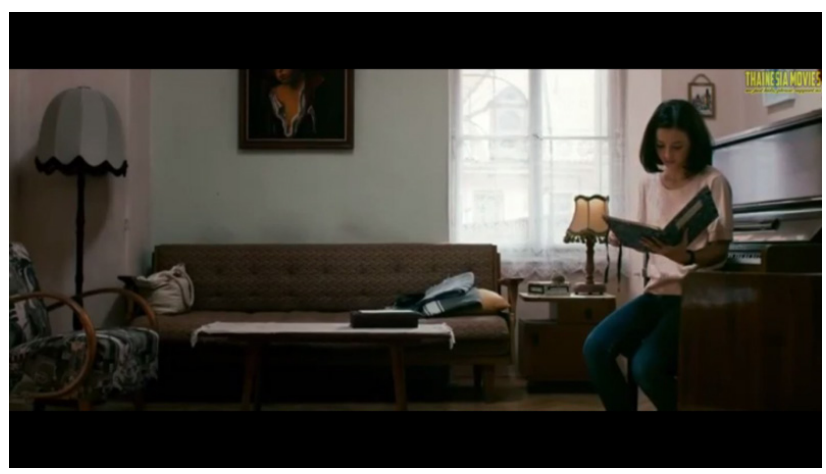

$00.36 .06-00.37 .40$

Sumber: Cuplikan Film Surat dari Praha

Tabel 12.

\section{Kekerasan}

\begin{tabular}{|c|l|l|}
\hline Simbol & \multicolumn{1}{|c|}{ Fungsi } & \multicolumn{1}{c|}{ Deskripsi Fungsi } \\
\hline$\delta$ & $\begin{array}{l}\text { Kekerasan } \\
\text { (F.III) }\end{array}$ & $\begin{array}{l}\text { Laras melanggar larangan yang diperintahkan oleh Jaya selama tinggal } \\
\text { di rumahnya. la membuka sebuah buku yang berada di atas piano dan } \\
\text { memainkan sebuah lagu yang berjudul "Sabda Rindu" yang terdapat dalam } \\
\text { buku tersebut. }\end{array}$ \\
\hline
\end{tabular}

Sumber: Olahan Penulis

Fungsi 2 dan 3 dalam fungsi narasi Propp merupakan elemen yang berpasangan yaitu adanya larangan yang tidak boleh dilanggar dalam sebuah cerita. Seperti dalam scene ini terlihat laras mengambil sebuah buku milik Jaya dan memainkan sebuah lagu yang terdapat pada buku itu dengan piano milik Jaya. Padahal pada Scene sebelumnya terdapat perintah dari Jaya untuk tidak menyentuh hal-hal yang tidak ada hubungannya dengan Laras selama tinggal di rumahnya. Fungsi ini ada akibat dari fugsi yang ke dua yaitu larangan yang tidak boleh dilanggar. Peristiwa ini termasuk fungsi ke tiga dengan lambang $\delta$.

11. Adegan Laras menyelidiki isi dari kotak surat yang dikirimkan oleh ibunya.

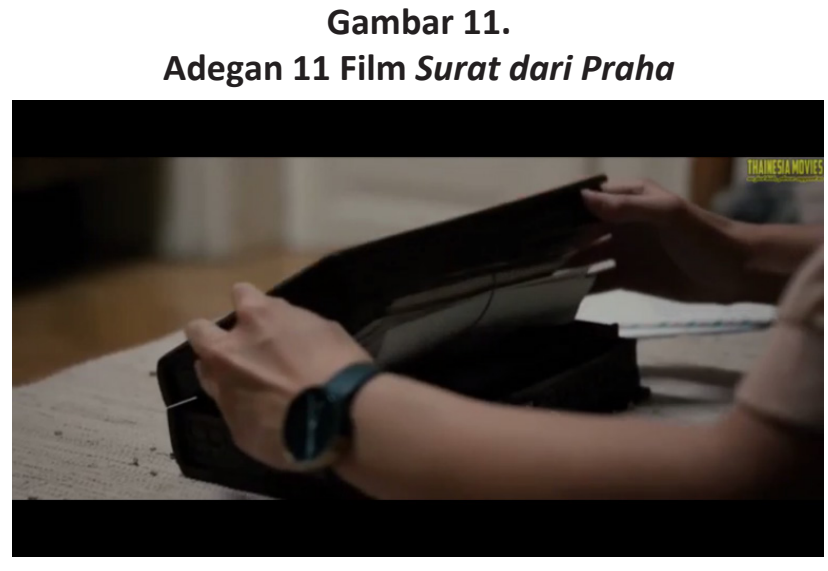

$00.38 .40-00.41 .24$

Sumber: Cuplikan Film Surat dari Praha 
Tabel 13.

Pengintaian

\begin{tabular}{|c|l|l|}
\hline Simbol & \multicolumn{1}{|c|}{ Fungsi } & \multicolumn{1}{c|}{ Deskripsi Fungsi } \\
\hline$\varepsilon$ & $\begin{array}{l}\text { Pengintaian } \\
\text { (F.IV) }\end{array}$ & $\begin{array}{l}\text { Laras melakukan usaha pengintaian dengan membuka kotak surat yang } \\
\text { dikirimkan oleh ibunya untuk Jaya. Serta membaca satu per satu surat dan } \\
\text { mencari informasi terkait apa isi di dalam surat tersebut. }\end{array}$ \\
\hline
\end{tabular}

Sumber: Olahan Penulis

Setelah memainkan lagu sabda rindu yang ditulis oleh Jaya. Laras penasaran dengan isi kotak yang dikirimkan oleh ibunya (Sulastri). Laras mulai membuka dan membaca satu per satu surat yang ada dalam kotak tersebut. Sampai akhirnya ia tahu bahwa surat-surat tersebut merupakan surat cinta yang ditulis Jaya untuk ibunya (Sulastri). Peristiwa ini tampak pada fungsi ke-4 dengan lambang $\mathrm{E}$.

12. Reaksi Laras setelah mengetahui isi dari suratsurat yang dikirlmkan Jaya kepada Ibunya.
Gambar 12. Adegan 12 Film Surat dari Praha

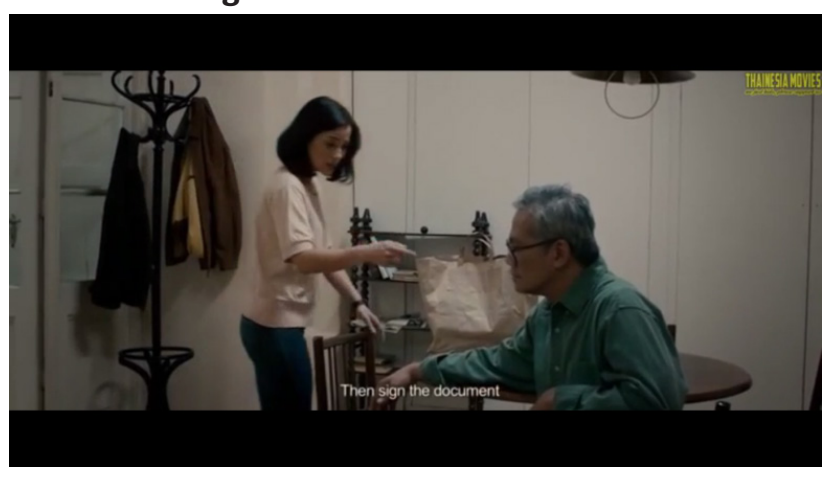

$00.41 .29-00.43 .27$

Sumber: Cuplikan Film Surat dari Praha

Tabel 14.

Reaksi dari Pahlawan

\begin{tabular}{|c|l|l|}
\hline Simbol & \multicolumn{1}{|c|}{ Fungsi } & \multicolumn{1}{c|}{ Deskripsi Fungsi } \\
\hline E & $\begin{array}{l}\text { Reaksi dari } \\
\text { Pahlawan } \\
\text { (F.XIII) }\end{array}$ & $\begin{array}{l}\text { Setelah mengetahui isi dari surat-surat yang dikirimkan Jaya kepada Ibunya. } \\
\text { Terjadi perdebatan antara Laras dengan Jaya. Laras menuding Jaya sebagai } \\
\text { perusak hubungan keluarga antara ibunya dengan ayahnya. }\end{array}$ \\
\hline
\end{tabular}

Sumber: Olahan Penulis

Laras : "Anda dan surat-surat ini merupakan penyebab orang tua saya jadi menderita ... anda penyebab kematian ayah saya!"

Jay : "saya tidak mengerti maksud kamu?"

Laras : "Anda mengirim seratus tigapuluh enam surat setelah menghilang selama puluhan tahun, tanpa kabar apapun, setelah kedua orangtua saya menikah selama sebelas tahun, pernah gak sih anda mikir, suratsurat ini tuh terlambat!"
Sebelumnya Laras tidak mengetahui alasan dirinya dikirim ke kota Praha, dan tidak mengetahui hubungan yang terjadi antara ibunya (Sulastri) dengan Jaya. Sampai akhirnya Laras mengetahuinya setelah pada adegan sebelumnya ia membuka dan membaca surat-surat yang ada di kotak tersebut. Di dalam scene ini diceritakan bahwa reaksi Laras setelah mengetahui isi dari surat-surat yang ia baca. Laras marah besar terhadap Jaya dan menuding sebagai perusak hubungan keluarganya. Peristiwa ini sesuai dengan fungsi narasi ke-13 yaitu reaksi dari pahlawan dengan lambang $E$. 
13. Keikhlasan Jaya untuk melupakan masa lalunya termasuk kisah cintanya dengan Sulastri.

Keikhlasan merupakan tema besar juga dalam film ini, menurut sang penulis Irfan Ramli, skenario yang ia buat selain menceritakan tentang drama/ romance yang dibalut dengan nuansa sejarah dan politik, cerita ini juga mengangkat tema garis besar keikhlasan. Di mana Jaya mengikhlaskan semuanya termasuk untuk tinggal di Praha setelah dicap pembelot oleh pemerintah Soeharto hanya karena tidak mengakui pemerintahannya dan masa lalunya untuk menikahi gadis impiannya Sulastri.
Gambar 13. Adegan 13 Film Surat dari Praha

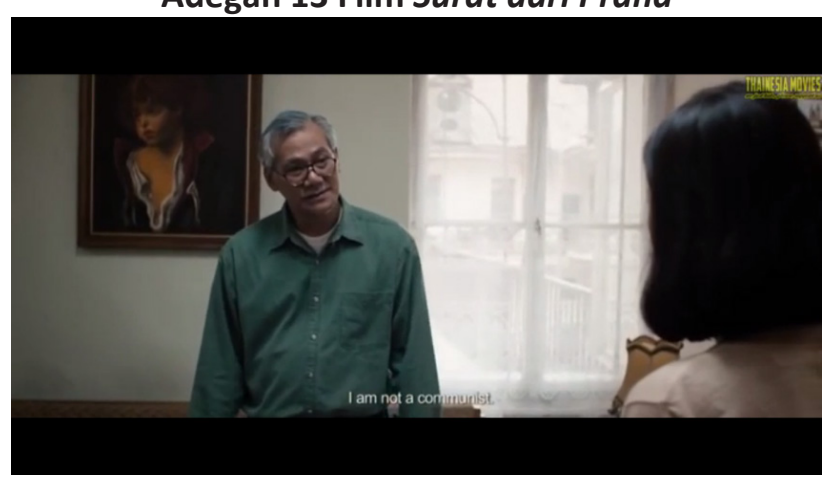

$00.45 .08-00.46 .05$

Sumber: Cuplikan Film Surat dari Praha

Tabel 15.

Tindakan Balasan

\begin{tabular}{|c|c|l|}
\hline Simbol & Fungsi & Deskripsi Fungsi \\
\hline C & $\begin{array}{c}\text { Tindakan } \\
\text { Balasan } \\
\text { (F.X) }\end{array}$ & $\begin{array}{c}\text { Jaya berusaha mencoba menjelaskan kepada Laras tentang kisah masa lalunya } \\
\text { dengan ibunya (Sulastri). Terhadap apa yang dituduhkan kepadanya atas } \\
\text { kekacauan hubungan keluarganya. }\end{array}$ \\
\hline
\end{tabular}

Sumber: Olahan Penulis

Jaya : "Memang terlambat tapi surat-surat ini dikirim bukan untuk mencelakakan siapapun.. hanya karena tidak dibalas.."

Laras : "Sabda rindu ditulis tahun Sembilan belas tujuh puluh dua .. ini setidaknya dua tahun sebelum ibu saya menikah .. kenapa anda gak pulang ke Indonesia?"

Jaya : "Anda mau tahu kenapa saya menolak pulang .. karena saya sudah mengikhlaskan semuanya .. masa lalu saya sudah saya ikhlaskan .. termasuk sulastri.. dan kalau saya mengikuti keinginan anda .. saya jadi manusia yang tidak konsisten .. jelas saya mencintai sisa-sisa hidup saya".

Laras : (terdiam)

Jaya : "Siapa namamu? Laras .. Larasati .. saya tidak ingin menceritakan masa lalu saya yang sudah saya ikhlaskan,, bahwa kedatanganmu di sini telah memberitahu saya banyak hal bahwa saya harus banyak berterima kasih .. tapi daun saja tidak siasia jatuh ke bumi .. saya punya alasan kenapa saya harus menghilang .. tidak memberi kabar .. terpaksa harus menghilang tepatnya .. tidak isa kembali ke tanah air .. dan itu semua bukan omong kosong".

Dalam peristiwa ini Jaya berusaha meyakinkan Laras terhadap apa yang dituduhkan kepadanya. Jaya menulis surat bukan karena niat mencelakakan seseorang, tetapi karena tidak dibalas, membuat ia terus menulis sampai akhirnya ia percaya bahwa surat itu tidak pernah sampai. Jaya berjuang menjelaskan kepada Laras bahwa ia telah mengikhlaskan masa lalunya termasuk kisah cintanya dengan Sulastri. Perjuangan Jaya untuk tetap tinggal dan harus kehilangan kewarganegaraan akibat menolak Orde Baru. Itu semua ia lakukan dengan sadar, serta perjuangan saat ini adalah menikmati masa tuanya dan mengikhlaskan semuanya. Peristiwa ini sesuai dengan perjuangan narasi Propp pada fungsi ke-16 dengan lambang $\mathrm{H}$.

14. Setelah perdebatan panjang mengenai masa lalunya, Jaya akhirnya bersedia untuk menandatangani surat tanda terima wasiat dari Sulastri.

Gambar 14. Adegan 14 Film Surat dari Praha

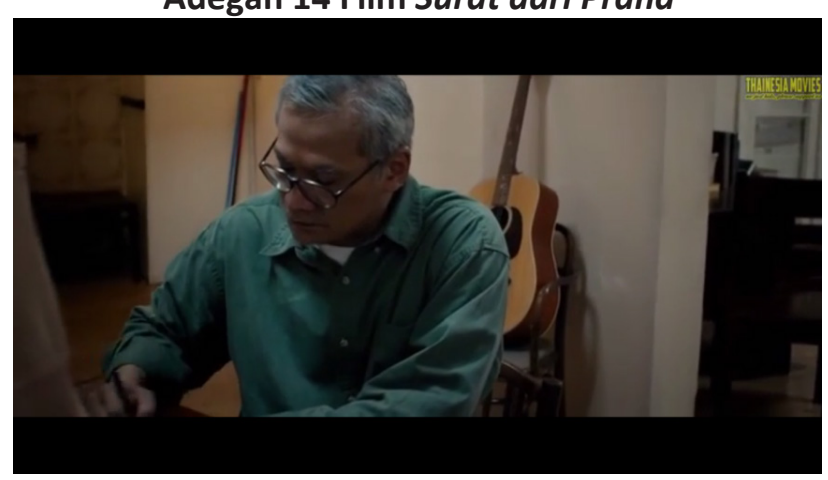

$00.47 .45-00.49 .26$

Sumber: Cuplikan Film Surat dari Praha 
Tabel 16.

Solusi

\begin{tabular}{|c|c|l|}
\hline Simbol & Fungsi & \multicolumn{1}{c|}{ Deskripsi Fungsi } \\
\hline $\mathrm{N}$ & $\begin{array}{c}\text { Solusi } \\
\text { (F.XXVI) }\end{array}$ & $\begin{array}{l}\text { Laras berhasil menyelesaikan tugas yang diberikan oleh ibunya. Dengan } \\
\text { mengantarkan kotak surat serta mendapatkan tanda tangan Jaya sebagai } \\
\text { syarat mendapatkan warisan. Walaupun sempat mendapatkan penolakan oleh } \\
\text { Jaya karena tidak mau menerima. Akhirnya Jaya mau menandatanganinya } \\
\text { setelah perdebatan panjang perihal masa lalunya yang telah ia ikhlaskan. }\end{array}$ \\
\hline
\end{tabular}

Sumber: Olahan Penulis

Laras : "Kalau anda sudah mengikhlaskan semuanya, seharusnya anda gak perlu menolak saya .. toh anda sudah ikhlas .. anda tinggal tanda tangan kertas itu .. dan semuanya selesai.."

Jaya : "Anda kesini hanya meminta tanda tangan saya, untuk mendapatkan warisan ibumu? Mana surat yang harus saya tanda tangani?"

Pada tahap ini solusi dalam narasi Propp yaitu tugas berhasil diselesaikan, lolos dari ujian dan bisa membuktikan dirinya adalah asli serta dapat menyelesaikan tugas yang diberikan. Pada peristiwa ini Laras berhasil mendapatkan tanda tangan Jaya walaupun harus dilalui dengan perdebatan panjang sebelumnya terkait isi surat-surat yang dikirimkan oleh Jaya yang ia tuding sebagai perusak hubungan keluarganya. Namun Jaya membantah dan telah mengikhlaskan masa lalunya dan mau menerima kotak tersebut dan menandatangani suratnya. Peristiwa ini sesuai dengan fungsi narasi ke-26 dengan lambang $\mathrm{N}$.
15. Pilihan emosianal dan berbagai macam peristiwa yang membuat jaya berjuang mempertahankan keyakinannya untuk tidak kembali ke Indonesia dan memilih bertahan hidup di Praha.

Gambar 15.

Adegan 15 Film Surat dari Praha

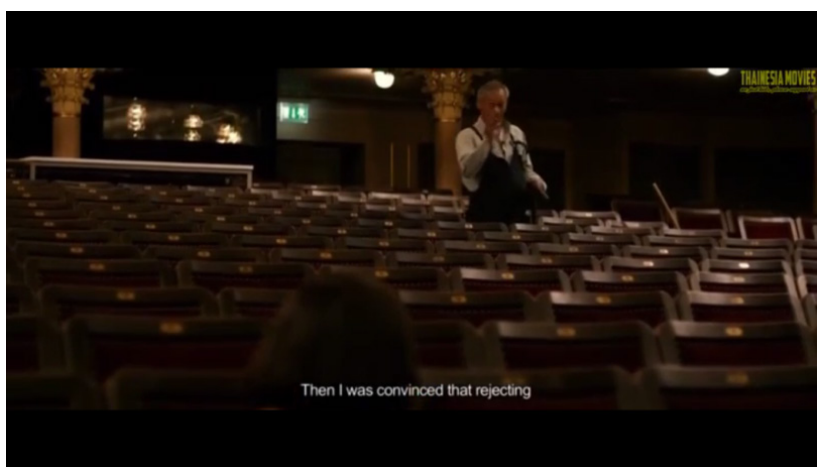

$01.01 .54-01.03 .44$

Sumber: Cuplikan Film Surat dari Praha

Tabel 17.

Perjuangan

\begin{tabular}{|c|c|l|}
\hline Simbol & Fungsi & \multicolumn{1}{c|}{ Deskripsi Fungsi } \\
\hline $\mathrm{H}$ & $\begin{array}{c}\text { Perjuangan } \\
\text { (F.XVI) }\end{array}$ & $\begin{array}{l}\text { Jaya menceritakan perjuangan hidupnya selama tinggal di Praha. Mulai } \\
\text { dari menolak orde baru yang dipimpin oleh Soeharto karena berbagai } \\
\text { alasan sampai berjuang bertahan hidup dengan bekerja apapun untuk } \\
\text { memenuhi kehidupan. }\end{array}$ \\
\hline
\end{tabular}

Sumber: Olahan Penulis

Jaya : "Pilihan emosianal awalnya .. tahun berganti .. rezim juga berganti ... berbagai peristiwaperistiwa yang kemudian menguatkan keyakinan bahwa .. Menolak adalah keputusan paling rasional .. tapi ada juga dari yang menolak kemudian mangkir dan membelot tapi saya tidak begitu .."

Laras : "Jadi dulu hanya bertahan dengan tujuh ratus crown dari pemerintah sini?"

Jaya : "Gak mungkin! .. sebab hidup kan perlu makan .. perlu nyuci dan lainnya .. meskipun disini sekolahnya gratis .. waktu itu kita mengerjakan apa saja .. wes macem-macem .. sebab di negara sosialis pada waktu itu kalau tidak bekerja .. bisa masuk penjara .. itu melawan hukum .. jadi segala sesuatu harus dikerjakan untuk bertahan hidup .. tapi tak apa memang harus mahal harga sebuah keyakinan dan perjuangan itu .. tidak boleh murah .. semakin mahal semakin bagus!"

Pada peristiwa ini dijelaskan perjuangan Jaya untuk memilih bertahan pada keyakinannya akan 
peristiwa yang terjadi pada pemeritah orde baru sehingga semakin kuat untuk menolak adalah keputusan yang paling rasional. Sehingga Jaya harus berjuang bertahan hidup di kota Praha. Walaupun sekolah yang diberikan pemerintah Ceko gratis namun kebutuhan lainnya harus tetap dipenuhi, membuat Jaya dan teman-teman lainnya harus bekerja apapun. Hingga saat ini pada gambar terlihat Jaya bekerja membersihkan gedung pertunjukan. Pada kejadian ini sesuai dengan fungsi narasi ke-16 dengan lambang $\mathrm{H}$.

16. Jaya dan para Mahasiswa Ikatan Dinas (Mahid) menjelaskan alasan untuk tetap tinggal dan berjuang mempertahankan keyakinannya.
Gambar 16. Adegan 16 Film Surat dari Praha

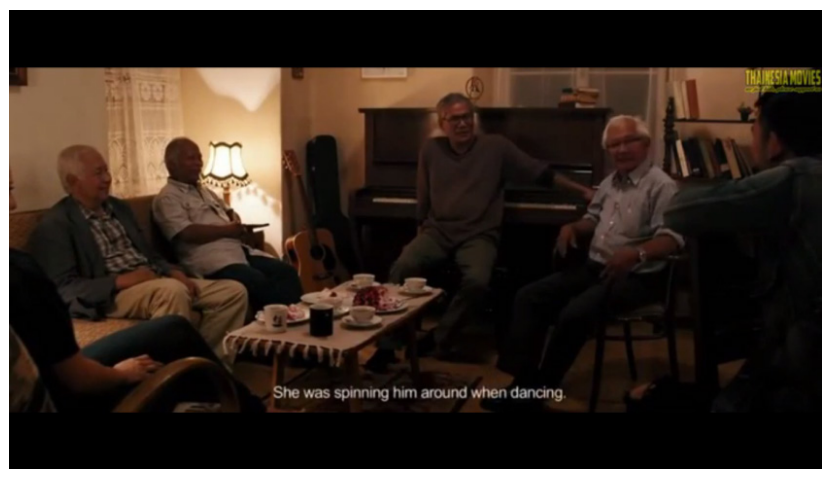

$01.16 .40-01.19 .50$

Sumber: Cuplikan Film Surat dari Praha

Tabel 18.

Pemaparan

\begin{tabular}{|c|c|l|}
\hline Simbol & Fungsi & Deskripsi Fungsi \\
\hline Ex & $\begin{array}{c}\text { Pemaparan } \\
\text { (XXVIII) }\end{array}$ & $\begin{array}{l}\text { Jaya bersama teman-teman mahasiswa ikatan dinas (Mahid) 1965 menjelaskan } \\
\text { alasannya untuk tetap tinggal di Praha, kepada Laras dan Dewa. }\end{array}$ \\
\hline
\end{tabular}

Sumber: Olahan Penulis

Rudi : "Makanya itu saya bilang, bahwa sejarah itulah sumber kekuatan .. ingatan tidak perlu di sortir!"

Laras : "Jadi dari yang menolak itu, enggak semuanya komunis?"

Jaya : "Ada sebagian.. tapi jauh lebih banyak dan besar adalah Nasionalis!!"

Rudi : "Yang jelas sebagian besar itu adalah pendukung Soekarno .. Soekarnoist"

Laras : "Lalu setelah menolak dan kehilangan passport?

Jaya : "Ya Stateless .. tidak punya kewarganegaraan!"

Rudi : "Yang jelas kita itu bukan pencari suaka .. karena waktu itu pemerintah Ceko keliatannya plintat-plintut terhadap pemerintah Soeharto ... dan kita berada dibawah perlindungan palang merah Cekoslovakia.

Teman Jaya : "Pada waktu itu blok timur sangat banyak menawarkan beasiswa dan kami akhirnya berangkat ... sampai akhirnya disini!"

*Kemudian dilanjutkan dengan menyanyikan lagu Indonesia Pusaka bersama-sama dengan diiringi piano yang dimainkan oleh Jaya.

Pada peristiwa ini diceritakan bahwa mereka Mahasiswa Ikatan Dinas (Mahid) yang menempuh perjalanan jauh untuk belajar harus rela kehilangan kewarganegaraan karena tidak menerima orde baru. Karena dicap pembelot oleh pemerintah Soeharto. Rudi salah seorang mahid menjelaskan bahwa tidak semua mahasiswa di sini adalah berideologi Komunis malahan sebagian besar adalah Nasionalis, dan sebagian besar merupakan pendukung dari Soekarno. Karena tidak memiliki kewarganegaraan mereka berjuang untuk bertahan karena passport dicabut oleh pemerintah Soeharto akhirnya mereka bernaung pada Palang Merah Cekoslovakia. Peristiwa ini sesuai dengan fungsi yang ke-28 yaitu pemaparan dengan lambang Ex.

Ke-31 fungsi yang dikemukakan oleh Propp adalah cerita yang sempurna, di mana setiap karakter dan fungsi terdapat dalam cerita. Sering kali terjadi, dalam cerita (narasi) tidak semua karakter dan fungsi ada. Sebuah cerita mungkin hanya memuat beberapa bagian saja dari karakter dan fungsi. Dalam analisis narasi, peneliti tidak perlu membuktikan atau menemukan ke-31 fungsi yang dikemukakan oleh Propp. Bisa jadi dalam sebuah narasi, hanya ditemukan beberapa fungsi saja (Erianto: 2013).

Dalam film Surat dari Praha terdapat 16 fungsi pelaku makna perjuangan yang diawali dengan situasi awal yang merupakan pengenalan pahlawan atau ksatria yaitu Kemala Dahayu Larasati (Laras) terhadap penonton atau penikmat film. Fungsi pelaku yang dialami tokoh-tokoh baik pahlawan, pengirim, penjahat atau pembekal itu diakhiri dengan pemaparan Jaya bersama teman- 
teman mahid berjuang hidup di negeri lain dan mengikhlaskan masa lalunya. Kemudian juga Laras yang telah berhasil menjalankan tugasnya sehingga ia bisa mendapatkan warisan ibunya setelah sebelumnya berhasil mengalahkan Jaya untuk menerima kotak dan menandatangani surat wasiat.

Dari fungsi-fungsi tersebut terjadi tidak hanya sekali namun juga ada pengulangan fungsi yang terjadi pada peristiwa yang berbeda. Seperti pada narasi ke 4 dan 8 sama-sama memiliki fungsi Mediasi. Struktur fungsi pelaku makna perjuangan dalam film Surat dari Praha apabila disusun yaitu sebagai berikut: $\alpha, M, \uparrow, B, A, R s, y, B, D, \delta, \varepsilon, E$, C, N, H, dan Ex.

Tabel 19.

Karakter Oposisi Berlawanan dalam Film Surat dari Praha

\begin{tabular}{|l|}
\hline \multicolumn{1}{|c|}{ Kepahlawanan } \\
\hline \multicolumn{1}{|c|}{ Pahlawan menjalankan misi tertentu atau } \\
menderita akibat tindakan penjahat. \\
Dalam film Surat dari Praha Laras mendapatkan \\
misi untuk menyerahkan kotak surat dan \\
mendapatkan tanda tangan Jaya. Sebagai syarat \\
untuk mendapatkan warisan. \\
Mengalami cobaan berat \\
Laras mengalami cobaan berat harus kehilangan \\
bayi yang dikandungnya serta selama menjalankan \\
misinya di Praha. Selain mengalami perampokan ia \\
juga mengalami penolakan dari Jaya.
\end{tabular}

\section{Diutus}

Laras diutus oleh tante Widia, seorang notaris keluarga. Untuk menyerahkan kotak surat tersebut kepada Jaya di Praha.

\section{Mendapatkan pertolongan kekuatan dari penderma}

Laras yang tadinya tidak memiliki harta termasuk pakaian mendapatkan pertolongan dari Loretta yaitu beberapa pakaian untuk dikenakan.

\section{Cinta}

Laras menjalankan tugas dengan tulus. Mau mengikuti apa yang diperintahkan oleh almarhum ibunya. Setelah mengetahui latar belakang Jaya, Laras kemudian menjadi lebih mengerti, mengenai alasan dan keyakinannya.

\section{Muda}

Sosok Laras digambarkan masih muda dan gagah.
Kejahatan

\section{Penjahat menghalangi misi pahlawan, menghukum pahlawan}

Ketika di perjalanan di kota Praha, Laras mengalami nasib yang buruk. Yaitu mengalami perampokan yang dilakukan oleh supir taksi. Sehingga harus kehilangan harta bendanya dan menghambat misinya

\section{Membuat Pahlawan mengalami cobaan}

Chico Jerikho berselingkuh dengan wanita lain pada saat Laras hamil 3 bulan hingga menyebabkan keguguran. Serta Jaya yang tidak mau menerima kotak surat dan tidak mau menandatanganinya.

\section{Bertindak Sendiri}

Setelah mendengarkan penjelasan dari Laras, tanpa alasan yang jelas. Jaya langsung menolak dan menyuruhnya keluar dari rumahnya

\section{Perpanjangan dari kekuatan jahat}

Supir taksi menggunakan senjata api berupa pistol. Untuk menakuti lalu merampok harta benda Laras.

\section{Benci}

Setelah mengetahui Laras dikirim oleh Sulastri, kekasihnya zaman dulu, Jaya langsung memerintahkan laras untuk keluar drari rumahnya dan membawa semua barang-barangnya termasuk kotak surat.

\section{Tua}

Sosok Jaya dan perampok digambarkan seorang yang sudah tua. 


\begin{tabular}{|c|c|}
\hline \multicolumn{1}{|c|}{ Perjuangan } & \multicolumn{1}{|c|}{ Jalan Pintas } \\
$\begin{array}{l}\text { Perjuangan Laras untuk menyerahkan dan } \\
\text { mendapatkan tanda tangan Jaya tidak didapatkan } \\
\text { begitu saja. la harus mengikuti apa yang di } \\
\text { perintahkan, dan beberapa kali melakukan } \\
\text { mediasi, sampai akhirnya Jaya mau menerima, } \\
\text { dan menandatanganinya. }\end{array}$ & $\begin{array}{l}\text { Supir taksi melakukan cara lain untuk mendapatkan } \\
\text { keuntungan dengan merampok penumpangnya. } \\
\text { Serta Jaya meminta Laras untuk memalsukan tanda } \\
\text { tangannya. }\end{array}$ \\
\hline \multicolumn{1}{|c|}{ Menemukan Sosok Penderma } & \multicolumn{1}{|c|}{ Menghambat Sosok Penderma } \\
$\begin{array}{l}\text { Laras menemukan sosok penderma yaitu } \\
\text { temannya di Indonesia yang bersedia } \\
\text { meminjamkan uang dan mentransfernya ke } \\
\text { Praha, untuk keperluan selama di Praha. }\end{array}$ & $\begin{array}{l}\text { Tanpa memberikan alasan yang jelas, Jaya menunda } \\
\text { untuk memberikan nomer rekening kepada } \\
\text { temannya Laras. }\end{array}$ \\
\hline $\begin{array}{l}\text { Laras berhasil menjalankan tugas yang } \\
\text { diperintahkan oleh almarhum ibunya, Jaya } \\
\text { mau menerima kotak surat tersebut dan } \\
\text { menandatangani surat penerimaan. }\end{array}$ & $\begin{array}{l}\text { Jaya akhirnya mau menandatangani Surat } \\
\text { penerimaan kotak surat, setelah sebelumnya terjadi } \\
\text { perdebatan dengan Laras terkait surat-surat yang ia } \\
\text { kirimkan. }\end{array}$ \\
\hline
\end{tabular}

Sumber: Olahan Penulis

\section{Karakter tokoh dalam Film Surat dari Praha}

Menurut Vladimir Propp, terdapat 5 karakter tokoh dalam narasi, berikut adalah analisis karakter tokoh yang terdapat dalam film Mencari Hilal, di antaranya:

\section{The Hero atau Pahlawan (Laras)}

Menurut Propp, Pahlawan adalah orang yang mengembalikan situasi kacau menjadi normal kembali. Walau tidak semua pahlawan dalam narasi digambarkan dengan tokoh yang gagah dan tampan.

Di dalam film ini seorang pahlawan diperankan oleh Jualia Estel yang memerankan tokoh Larasati. Sesuai dengan definisi pahlawan yang dikemukakan oleh Propp. Larasati dalam film Surat dari Praha telah menjalanan perintah wasiat dari ibunya (Sulastri) sebagai syarat untuk mendapatkan warisan. Yaitu konflik tentang masa lalu ibunya (Sulastri) dengan seorang pria yang bernama Jaya.

2. Villain atau Penjahat (Chicco Jerikho, Supir Taksi dan Jaya)

Tokoh Villain atau penjahat pada narasi Propp menggambarkan seseorang yang melukai pahlawan, tindakan penjahat menyebabkan kerugian atau cedera baik pada pahlawan maupun anggota lainnya (Erianto: 2013). Pada film ini yang menjadi penjahat adalah Chicco
Jerikho yang berperan sebagai suami Laras, la berselingkuh dengan wanita lain pada saat Laras hamil sehingga menyebabkan keguguran. Kemudian supir taksi di kota Praha, yang merampok pahlawan (Laras) sehingga harus kehilangan seluruh harta bendanya. Kemudian Jaya yang tidak mau menerima Laras dan menghalangi dalam menyelesaikan tugasnya.

\section{The Donor atau Penderma (Loretta)}

Menurut Propp, Penderma adalah orang yang memberikan sesuatu kepada pahlawan, baik berupa benda, informasi ataupun nasihat. Menolong pahlawan dengan kekuatan magic (supranatural).

Penderma dalam film ini ditokohkan oleh Loretta. beliau merupakan wanita asal Ceko yang memberikan pakaian dan handphone kepada Laras untuk dipakai dan digunakan selama di Praha. Karena sebelumnya laras mengalami perampokan sehingga harus kehilangan harta bendanya.

\section{Helper atau Penolong (Polisi dan Jaya)}

Penolong dalam film ini ditokohkan oleh Polisi yang membantu Laras untuk diantarkan ke sebuah alamat setelah mengalami perampokan. Serta Jaya yang menolong Laras untuk tinggal sementara dirumahnya. 
Sesuai dengan definisi dari Helper atau penolong dalam narasi adalah orang yang secara langsung membantu pahlawan dalam mengalahkan dan mengembalikan situasi kembali kepada situasi normal.

\section{Putri dan Ayah sang putri}

Dalam film ini karakter ayah sang putri digantikan oleh ibunya Laras yaitu Sulastri karena yang memberikan tugas berat kepada Laras dalam film Surat dari Praha adalah ibunya dan tidak ada sosok Putri dalam film ini.

\section{Dispatcher atau Pengirim (Widia)}

Pengirim dalam narasi digambarkan sebagai orang yang mengirim pahlawan untuk menyelesaikan tugas dalam melawan penjahat. Widia atau notaris kelaurga merupakan pengirim (dispatcher) dalam film Surat dari Praha. Beliau yang mengutus Laras untuk pergi menemui Jaya di kota Praha. Untuk menyerahkan sebuah kotak dan mendapatkan tandatangannya. Sebagai syarat mendapatkan warisannya.

\section{The False Hero atau Pahlawan Palsu}

Dalam film ini tidak ada pahlawan palsu.

\section{SIMPULAN}

Untuk menyimpulkan hasil penelitian ini, peneliti mengacu pada fokus permasalahan yang ada dengan melihat pada pendekatan teori dan implementasinya pada objek penelitian. Karena itu, peneliti menyimpulkan ada enam belas adegan yang mengandung unsur perjuangan. Film ini merupakan film drama, namun dibuat berdasarkan realita yang ada. Banyak adegan yang menarik dalam film ini. Namun ada beberapa adegan yang memperlihatkan produk kopi dan permen, dan itu sangat menganggu, di tengah pesan yang ingin disampaikan terselip iklan suatu produk itu rasanya tidak begitu nyaman dilihat.

\section{DAFTAR PUSTAKA}

Berger, A. A. (2003). Media and Society: A Critical Perspective. Boulder: Rowman and Littlefield Publishers.

Burton, G. (2006). Yang Tersembunyi di Balik Media; Pengantar Kepada Kajian Media. Yogyakarta: Jalasutra.
Budiharsono, S. (2003). Politik Komunikasi. Jakarta: Grasindo.

Eriyanto. (2013). Analisis Naratif: Dasar-dasar dan penerapannya dalam Analisis Teks Berita Media. Jakarta: Kencana Prenada Media Group.

Prakoso, G. (1997). Film Pinggiran-Antologi Film Pendek, Eksperimental \& Documenter. Jakarta: Fatwa Press.

Pratista, H. (2008). Memahami Film. Yogyakarta: Homerian Pustaka.

Sobur, A. (2001). Analisis Teks Media-Suatu Pengantar Untuk Analisis Wacana, Analisis Semiotik, Dan Analisis Framing. Bandung: PT. Remaja Rosdakarya.

Suryapati, A. (2010). Hari Film Nasional tinjauan dan Restrospeks. Jakarta: Panitia hari Film Nasional Ke-60 Direktorat Perfilman.

Santana, S. (2005). Jurnalisme Kontemporer. Jakarta: Yayasan obor Indonesia.

Stokes, J. (2007). How to media and cultural studies: panduan untuk melaksanakan penelitian dalam kajian media dan budaya. Yogyakarta: Bentang Pustaka.

www.goodnewsfromindonesia.id

www.republika.co.id 